\title{
POSTAWY RODZINY WOBEC GRY W POKERA - WYNIKI BADAŃ JAKOŚCIOWYCH GRACZY REKREACYJNYCH I ZAWODOWYCH
}

\author{
ATTITUDES OF A FAMILY TOWARDS POKER - \\ THE RESULTS OF A QUALITATIVE STUDY OF POKER RECREATIONAL \\ AND PROFESSIONAL PLAYERS
}

\begin{abstract}
A b s t r a c t. Playing poker is quite a popular pastime, but it can be also an unusual form of work. Nevertheless, it can become an addiction having negative consequences for an individual person and the society, moreover, it is not accepted in this society. Therefore, players' families may be concerned about the outcomes of taking up this game. It is confirmed by the results of the qualitative studies described in this article ${ }^{1}$. There were conducted 30 in-depth interviews with recreational and professional poker players aged 19-30, the purpose of which was, for example, to provide information on the family situation of poker players. The article presents the results related to the families' attitudes towards the game, which were mostly full of fears and doubts. There were described reasons of their negative attitudes usually conditioned by the mechanisms of the social life and the fear of becoming addicted to the game, as well as their consequences related to further plans of the players. The article also mentions family relationships playing an important role in the acceptance of the game of poker.
\end{abstract}

Key words: poker; gambling; family; addiction; social acceptance.

Mgr Anna Grzesik - Instytut Psychologii, Wydział Pedagogiki i Psychologii Uniwersytetu Marii-Curie Skłodowskiej; e-mail: anna.grzesik215@gmail.com

${ }^{1}$ Praca naukowa finansowana ze środków budżetowych na naukę w latach 2015-2019 jako projekt badawczy w ramach programu pod nazwą „Diamentowy Grant” (projekt nr DI2014 000844). 


\section{WSTĘP}

Poker to gra karciana, która jest jedną z najszybciej rozwijających się gier hazardowych ${ }^{2}$. Od wielu lat jest dość popularną formą rozrywki na całym świecie (również w Polsce), szczególnie wśród mężczyzn. O powszechności gier hazardowych donoszą raporty z badań prowadzonych w różnych krajach świata. Dla przykładu: raport brytyjskiego National Center for Social Research traktujący o aktywności hazardowej wskazuje, że 73\% mieszkańców Wielkiej Brytanii $\mathrm{w}$ wieku powyżej 16 lat uprawiało hazard w różnych formach ${ }^{3}$. Z kolei badania przeprowadzone wśród mieszkańców jednego ze stanów Australii wykazały, że w ciągu ostatniego roku w grach hazardowych uczestniczyło $65 \%$ respondentów ${ }^{4}$. Co więcej, w hazard angażują się nie tylko dorośli, ale również młodzież. Jak wynika z badań przeprowadzonych przez Fundację Dajemy Dzieciom Siłę (ówczesną Fundację Dzieci Niczyje) wśród uczniów trzecich klas gimnazjum z 7 krajów, 6,3\% przebadanych osób uprawia hazard przez internet ${ }^{5}$. Grę w pokera jako osobną kategorię wyodrębnia się w niewielu badaniach, z wyżej przytoczonych mówi o niej raport $\mathrm{z}$ badań prowadzonych wśród Brytyjczyków - według niego $\mathrm{w}$ grze w pokera w kasynach lub klubach uczestniczyło $2 \%$ respondentów.

\section{UZALEŻNIENIE OD HAZARDU}

Hazard patologiczny jest jednym z najczęściej spotykanych uzależnień behawioralnych, które mogą się rozwinąć po wielokrotnym powtarzaniu danej czynności. Jego skutki obejmują nie tylko samego gracza, ale także jego rodzinę i dalsze otoczenie. Dla patologicznego hazardu sformułowano kryteria diagnostyczne w ramach klasyfikacji zaburzeń psychicznych Amerykańskiego Stowarzyszenia Psychiatrycznego z 2013 r. (DSM-V), w której zaliczony został do kategorii zaburzeń dotyczących nadużywania substancji i zachowań (Substance-Related and

2 M. Dufour, N. Brunelle, E. Roy, Are Poker Players All the Same? Latent Class Analysis, „Journal of Gambling Studies” 2015, nr 31, s. 441-454.

${ }^{3}$ H. Wardle, A. Moody, S. Spencer, J. Orford, R. Volberg, D. Jotangia, M. Griffiths, D. Hussey, F. Dobbie, British Gambling Prevalence Survey 2010, National Center for Social Research 2010, s. 9.

${ }^{4}$ K. Sproston, N. Hing, Ch. Palankay, Prevalence of Gambling and Problem Gambling in New South Wales, Sydney: NSW Office of Liquor, Gaming and Racing 2012, s. IV.

${ }^{5}$ K. MakaruK, S. WóJcik, EU NET ADB - Badanie nadużywania internetu przez młodzież w Polsce i Europie. Raport z badań, Warszawa: Fundacja Dzieci Niczyje 2012, s. 8. Strona internetowa: fdds.pl/wp-content/uploads/2016/05/Makaruk_Wojcik_EU-NET-ADB_raport_PL.pdf. 
Addictive Disorders) ${ }^{6}$. „Uprawianie hazardu” umieszczono także w klasyfikacji ICD-11, w podgrupie "Zachowania uzależniające”7.

Według szacunków opracowanych na podstawie badań przeprowadzonych przez Centrum Badania Opinii Społecznej w 2012 r., zagrożonych uzależnieniem od grania jest 3,7\% dorosłych Polaków, a wśród grających wskaźnik ten sięga aż 16\%, gdzie większość z nich to mężczyźni ${ }^{8}$. Badania przeprowadzone przez tę samą instytucję w 2015 r. wskazują na szacunkową liczbę osób leczonych w Polsce z powodu hazardu wynoszącą 3141 pacjentów oraz liczbę osób uprawiających patologiczny hazard sięgającą 27955 graczy $^{9}$. Badania przeprowadzone w 2014 r. na polskich graczach pokerowych przez autorkę artykułu oraz R. Mudę i P. Śliwińską wykazały, że zagrożonych uzależnieniem jest 3,3\% badanych osób ${ }^{10}$. Uzależnienie od hazardu przebiega podobnie jak każdy inny rodzaj uzależnienia. Pierwszy kontakt $\mathrm{z}$ hazardem często jest formą rozrywki i ma wymiar towarzyski, a podczas jednej z pierwszych gier zdarza się tzw. wielka wygrana, która wywołuje w graczu emocje nasilające chęć i potrzebę dalszej gry ${ }^{11}$.

\section{REKREACYJNA I ZAWODOWA GRA W POKERA}

Przez lata można było obserwować rozwój gry w pokera oraz zmierzanie w kierunku niemalże zgody ze strony różnych środowisk co do tego, że poker ma inny charakter niż gry hazardowe, w których decydujący jest czynnik losowości (np.

${ }^{6}$ American Psychiatric Association, Diagnostic and Statistical Manual of Mental Disorders Fifth Edition, Washington 2013.

${ }^{7}$ W. Gaebel, J. ZielaseK, G.M. Reed, Zaburzenia psychiczne i behawioralne w ICD-11: koncepcje, metodologie oraz obecny status, „Psychiatria Polska” 2017, nr 51(2), s. 169-195, wydanie internetowe: doi.org/10.12740/PP/69660.

8 B. Badora, M. Gwiazda, M. Herrmann, J. Kalka, J. Moskalewicz, Oszacowanie rozpowszechnienia oraz identyfikacja czynników ryzyka i czynników chroniacych $w$ odniesieniu do hazardu, w tym hazardu problemowego (patologicznego) oraz innych uzależnień behawioralnych, Warszawa: Centrum Badania Opinii Społecznej 2012, s. 170-171.

9 B. Badora, M. Gwiazda, M. Herrmann, J. Kalka, J. Moskalewicz, Rozpowszechnienie wybranych uzależnień behawioralnych i ich zwiazek z używaniem substancji psychoaktywnych, Warszawa: Centrum Badania Opinii Społecznej 2015, s. 80.

${ }^{10}$ R. Muda, P. ŚLIWińska, A. Pawelec, I-graj z losem dzięki umiejętnościom. Jakie czynniki zwiazane sa z wysokimi osiagnięciami finansowymi w grze w pokera?, „Psychologia Ekonomiczna” 2014, nr 5, 26-28, wydanie internetowe: https://psychologia-ekonomiczna.com.pl/article/view/226.

${ }^{11}$ B. LeloneK-Kuleta, Uzależnienie od grania hazardowego w rodzinie na tle wybranych kultur, w: Rodzina i tradycja - na pograniczu kultur i czasów, red. J. Gorbaniuk, Lublin-KijówLwów 2015, s. 124-144. 
gra na automatach czy ruletka). Elementem, który wyróżnia pokera, jest udział czynników osobowościowych i rola umiejętności, które w dłuższej perspektywie są kluczowe do utrzymywania dobrych wyników w grze ${ }^{12}$. W literaturze znaleźć można porównanie pokera do gier sportowych, takich jak szachy czy brydż, opierające się na twierdzeniu, że doświadczenie pomaga graczom pokerowym podejmować decyzje na podstawie prawidłowości statystycznych, a nawet osiągać ekspercki poziom gry ${ }^{13}$. Udaje się to głównie graczom nazywanym pokerzystami zawodowymi (w zagranicznej literaturze powszechny jest podział graczy na rekreacyjnych i zawodowych, inaczej zwanych profesjonalnymi ${ }^{14}$ ). Są to osoby, dla których gra w pokera stanowi główne lub jedyne źródło dochodu. Ponadto gracze zawodowi poświęcają na samą grę oraz na naukę gry wiele czasu, podejmują na ogół mniej ryzykowne decyzje w stosunku do graczy rekreacyjnych, cechują się większą kontrolą i zdyscyplinowaniem w grze ${ }^{15}$. Gracze rekreacyjni natomiast częściej podejmują grę pod wpływem alkoholu i innych używek, ponadto mają większą tendencję do „odgrywania się”, czyli zwiększoną potrzebę kontynuowania gry po doznaniu straty w celu jej odrobienia. Są to cechy graczy tworzące profil tzw. typowego hazardzisty ${ }^{16}$.

\section{METODA I PRÓBA: BADANIA JAKOŚCIOWE}

Artykuł napisany został na podstawie wywiadów pogłębionych częściowo ustrukturyzowanych przeprowadzonych z graczami pokerowymi w różnych miastach Polski (Rzeszów, Lublin, Zamość, Kraków, Katowice, Jędrzejów, Wrocław, Mińsk Mazowiecki, Warszawa, Łódź, Radom, Puławy, Gdańsk, Pruszcz Gdański, Koszalin, Kielce). Wywiady to część szerszych badań o charakterze podłużnym, podzielonych na 3 etapy: internetowe badania ankietowe, wywiady pogłębione

${ }^{12}$ M. Czajkowni, Poker - gra szczęścia czy umiejętności? Przegląd analiz teoretycznych i empirycznych oraz wnioski dla regulacji, „Ekonomia” 2015, nr 40, s. 33-57.

13 D. Kahneman, Pułapki myślenia: o myśleniu szybkim i wolnym, Poznań: Media Rodzina 2012, s. 195.

${ }^{14}$ R. Biolcati, S. Passini, M.D. Griffiths, All-in and Bad Beat: Professional Poker Players and Pathological Gambling, „International Journal of Mental Health and Addiction” 2014, nr 13, s. 19-32.

15 A.A.B. Hopley, J. Wagner, R. Nicki, Making a Living Online: Problem Gambling and Workaholism in High Earning Online Texas Hold'em Poker Players, „Journal of Gambling Issues” 2014, nr 29, s. 1-18.

${ }^{16}$ Z. Mielecka-Kubień, J. Biolik, K. Warzecha, A. Wóıcik, Wybrane aspekty społecznoekonomicznych skutków uzależnienia od hazardu, „Zeszyty Naukowe Uniwersytetu Ekonomicznego w Krakowie" 2015, nr 4(940), s. 85-99. 
oraz ponowne badania ankietowe. Ich celem jest zbadanie epidemiologii gry w pokera przez internet wśród mężczyzn w wieku 19-30 lat, określenie skali gry problemowej w zakresie pokera w Polsce oraz jej dynamiki na przestrzeni lat, a także poznanie specyfiki grupy graczy pokerowych - rekreacyjnych i zawodowych. Badania prowadzone były od 2016 do 2019 r.

W badaniach jakościowych wzięło udział 30 grających w pokera mężczyzn, w wieku od 19 do 30 lat. Respondentów podzielono na dwie grupy: 15 graczy zawodowych (wygrane z pokera stanowią więcej niż 50\% dochodu badanego) oraz 15 graczy rekreacyjnych (wygrane z pokera 50\% dochodu gracza lub mniej).

Opisywane badania mają charakter eksploracyjny, nastawione są na poszukiwanie odpowiedzi na postawione pytania, ale także poznanie subiektywnej perspektywy respondentów, stąd wybór podejścia jakościowego, które wymagane jest w takich przypadkach ${ }^{17}$. Głos oddany jest w całości osobom badanym, a przedmiot otwartej analizy stanowią ich swobodne, naturalne oceny i opinie. Wywiady obejmowały obszary tematyczne dotyczące bezpośrednio gry w pokera oraz tematy pokrewne: zdefiniowanie gry w pokera $\mathrm{z}$ uwzględnieniem charakteru gry (poker jako hazard, sport itp.), aspekty pomagające i utrudniające zdobywanie sukcesu w grze (szczęście, umiejętności, cechy osobowości itp.), historia gry w pokera danej osoby, motywacja do gry, dokształcanie się w zakresie pokera, ewentualne granie problemowe, gra w pokera przez internet, dostępność internetu i korzystanie z niego poza grą, sytuacja finansowa gracza, gra w pokera na tle sytuacji rodzinnej, ewentualny problem z innymi uzależnieniami.

Jedną z kwestii poruszanych podczas wywiadu był aspekt rodzinny. Rozmówcy pytani byli o ogólną sytuację rodzinną, jakość kontaktu z rodzicami, wartości przekazane przez rodziców i ich zgodność z tymi, którymi kierują się we własnym życiu, założenie (lub nie) własnej rodziny, reakcje członków rodziny na grę w pokera badanego i związane z tym decyzje odnośnie do dalszej gry, wpływ gry w pokera na relacje $\mathrm{z}$ rodzicami oraz $\mathrm{z}$ dziewczyną lub żoną.

Na tematy związane z sytuacją rodzinną wypowiedziało się 27 respondentów (15 graczy rekreacyjnych, oznaczanych poniżej literą „R” i 12 zawodowych, oznaczanych literą „Z”), pozostali trzej niechętnie odpowiadali na pytania dotyczące rodziny, więc wątki te nie były rozwijane. To właśnie do liczby 27 badanych będą odnosić się wszystkie poniższe dane. Wśród tych osób wszyscy grali w pokera co najmniej od 2 lat, a najdłuższy staż gry to 15 lat i dotyczy gry zawodowej. Czterech badanych założyło własne rodziny, wchodząc w związek

${ }^{17}$ N.K. Denzin, Y.S. Lincoln, Introduction: the discipline and practice of qualitative research, w: Handbook of qualitative research, red. N.K. Denzin, Y.S. Lincoln, Thousand Oaks CA: Sage Publications 2005, s. 1-45. 
małżeński, 15 pozostaje w związkach nieformalnych, pozostałych ośmiu to single. Większość respondentów (11) mieszka z partnerką, ośmiu ze znajomymi, czterech samodzielnie, czterech nadal mieszka z rodzicami. Wszyscy deklarują samodzielność finansową.

Badani wypełnili dodatkowo kwestionariusz CPGI (Canadian Problem Gambling Index), mierzący stopień zagrożenia uzależnieniem od gry ${ }^{18}$. Wśród 27 badanych u 19 (70\%) nie występuje problem, ośmiu (30\%) wykazuje niski poziom ryzyka, u dwóch (poniżej 1\%) występuje umiarkowany poziom ryzyka dotyczącego grania problemowego (należy zaznaczyć, że były to wyniki na początku tego przedziału).

\section{WYNIKI BADAŃ WŁASNYCH}

Jednym $\mathrm{z}$ tematów poruszanych podczas wywiadu była reakcja rodziny na zamiar lub fakt zaangażowania się $\mathrm{w}$ grę w pokera na pieniądze. To pytanie wywoływało w rozmówcach wiele emocji i chęć podzielenia się swoimi doświadczeniami. Większość rozmówców (25 osób, czyli 93\% respondentów wypowiadających się na tematy dotyczące rodziny) przyznało, że ich wybór był trudny do zaakceptowania. Najczęstszą reakcją bliskich był sprzeciw wobec gry. Zazwyczaj związany był z lękiem przed uzależnieniem, podpartym świadomością zagrożeń płynących z grania hazardowego. Drugą powszechną postawą rodzin, zwłaszcza rodziców, była obawa przed odrzuceniem ze strony różnych grup społecznych, wynikająca z braku akceptacji gry w pokera w społeczeństwie. Rodzice i partnerki niektórych graczy z czasem zaakceptowali pokera jako formę rozrywki lub zarobku, jednak często nawet $w$ tych przypadkach nie pozbyli się całkowicie niepewności wynikającej ze specyfiki gry i jej odbioru przez społeczeństwo.

\subsection{LĘK BLISKICH PRZED UZALEŻNIENIEM OD GRY W POKERA}

Dane dotyczące grania problemowego są obecnie powszechnie dostępne i znane nawet osobom niezajmującym się tematyką hazardu. To właśnie te informacje sprawiają, że wiadomość o zaangażowaniu bliskiej osoby w grę hazardową wywołuje silny niepokój i obawy przed uzależnieniem. Ponadto gra

18 J. Ferris, H. Wynne, The Canadian Problem Gambling Index: Final Report, Ottawa: Canadian Centre on Substance Abuse 2001. 
odbywa się zazwyczaj w tzw. szarej strefie, ponieważ w Polsce istnieje obecnie niewiele możliwości legalnej gry.

O tym, że bliscy zareagowali lękiem przed wpadnięciem w sidła uzależnienia od hazardu, wspomniało aż 22 respondentów (81\% badanych poruszających ten temat). Zazwyczaj rodzice graczy od razu wyznawali, że martwią się o syna, boją się, że wpadnie w uzależnienie. Przykładowe wypowiedzi obrazujące lęk rodziców: „Mama od razu powiedziała: synu, coś ty wymyślił! Jeszcze nam hazardzisty w rodzinie brakuje!” (R9, lat 23); „Moi rodzice nie za bardzo się ucieszyli, jak się dowiedzieli, że zacząłem grać. Od razu skojarzenia, wiadomo, patologia, hazard... Powiedzieli, że mam sobie dać z tym spokój, bo to się źle skończy i żebym nie wracał potem z płaczem, bo mi brakuje na długi” (R3, lat 21). Rodzice niektórych graczy podejmowali nawet dalsze kroki w obawie przed uzależnieniem syna od gry: „Pamiętam... rodzice właśnie zaniepokojeni moją grą w pokera w liceum wysłali mnie do psychologa” (Z2, lat 27).

Rodzice wielu graczy zawodowych (8 osób) otwarcie przyznawali, że nie podoba im się taki sposób na zarabianie pieniędzy, widząc w tym zagrożenie: „Ojciec krzyczał, matka prawie się rozpłakała, jakbym już co najmniej zastawił dom i psa. Nie wiem, czy w ogóle do nich dotarło, że na tym da się zarobić i nie wpaść w patologię" (Z5, lat 21). W wielu przytoczonych przez respondentów wypowiedziach widoczne są silne emocje, które towarzyszyły ich bliskim. Łatwo zauważyć również utożsamianie przez rodziny samej gry w pokera z graniem patologicznym oraz przewidywanie najbardziej negatywnych skutków uzależnienia od hazardu.

\subsection{OBAWY RODZIN DOTYCZĄCE SPOŁECZNEJ AKCEPTACJI POKERA}

Niemal równie ważnym aspektem w odbiorze informacji o zaangażowaniu w grę w pokera, obok obawy przed uzależnieniem, był czynnik akceptacji społecznej. Żadna rodzina nie żyje w odosobnieniu, lecz ma strukturalne powiązanie ze środowiskiem, w którym funkcjonuje i z którym wchodzi w interakcje ${ }^{19}$, a człowiek, jako istota społeczna, wykazuje silną potrzebę przynależności i więzi emocjonalnych oraz akceptacji ze strony grup społecznych, do których przynależy ${ }^{20}$. Taką grupą społeczną jest rodzina, ale też inne grupy, które jednostka tworzy w ciągu życia: znajomi, z którymi się spotyka, czy ludzie, z którymi pracuje. Członkostwo w grupie społecznej jest elementarną cechą

19 S. DZIERZYŃSKa-Breś, Sytuacja społeczna rodzin osób pozbawionych wolności, Poznań: Wydawnictwo Naukowe UAM 2016, s. 29.

${ }^{20}$ H. HAmer, Psychologia społeczna: teoria i praktyka, Warszawa: Difin 2005, s. 281. 
życia społecznego, dzięki której człowiek poznaje wartości, zaspokaja potrzeby, może także gromadzić różne zasoby ${ }^{21}$. Ponieważ przynależność do każdej grupy daje wymierne korzyści, wszyscy członkowie dążą do jej utrzymania. Co więcej, potrzeba przynależności jest niezwykle silną motywacją, wpływającą na ludzi w sferze poznawczej, emocjonalnej i behawioralnej ${ }^{22}$. Może to być jednym z najprostszych, lecz jednocześnie najtrafniejszych wyjaśnień sprzeciwu rodziców młodych osób wobec gry w pokera. Nie zostałaby ona zaakceptowana w grupach społecznych, do których należą, gdyż poker utożsamiany jest z hazardem i może budzić skojarzenia z obrazem patologicznego hazardzisty.

W wypowiedziach 21 badanych (78\%) pojawiły się wzmianki o tym, że rodzice mieli opory, aby przekazać informacje o graniu w pokera swoim znajomym i dalszej rodzinie. Gracze słyszeli w związku z tym określenia typu: „wstyd”, „nie wypada”, „głupota”, „patologia”. Jeden z respondentów przytoczył słowa swojej matki: „To niepoważne, żeby zawodowo grać w karty. Wszyscy nas wyśmieją, a potem będą za plecami gadać, że mamy syna hazardzistę" (Z7, lat 25). Inny gracz wyznał: „Rodzice powiedzieli, że przynoszę im wstyd, że jak oni spojrzą w oczy rodzinie, jak już wszyscy się dowiedzą. Jakbym był jakimś kryminalistą" (R14, lat 23).

Pokerzyści zawodowi wskazywali na jeszcze jeden problem powiązany z brakiem akceptacji społecznej wobec gry w pokera. Często poruszali temat prestiżu zawodowego i odnosili go do pozycji zawodowej swoich rodziców, zazwyczaj ojców. Ten wątek poruszyło 6 osób (z 12 graczy profesjonalnych wypowiadających się na tematy związane z rodziną), co stanowi 50\% tej grupy badanych. Gracze opowiadali o tym, że ich rodzice osiągnęli wysoką pozycję zawodową i zarobki, wykonują pracę wiążącą się z prestiżem społecznym, nierzadko prowadzą własne firmy i cieszą się uznaniem w lokalnej lub w szerszej społeczności. To wywołuje w nich chęć dorównania rodzicom w tej sferze, a także lęk przed sprawieniem im zawodu, gdyż często wysoka pozycja zawodowa rodziców wiąże się z równie wysokimi oczekiwaniami względem zawodu wybranego przez ich dziecko. Przykładowe wypowiedzi na ten temat brzmiały: „Nawet nie chcieli o tym słuchać. Powiedzieli, żebym sobie wybił z głowy takie pomysły i znalazł normalną, poważną pracę, żeby się nie musieli wstydzić przed ludźmi” (Z9, lat 22); „Zawsze chciałem dorównać rodzicom. Oni byli w życiu kimś, prowadzili swój biznes, mieli dużo pieniędzy i czasem sami mówili, że to jest w życiu ważne. Wiem, że w sensie finansowym na pokerze wyszedłbym dobrze, ale reszta

${ }^{21}$ W. Kubiak-Krzywicka, Interakcyjno-kontekstualny model zaburzonej socjalizacji, Poznań: Wydawnictwo Naukowe UAM 2010, s. 39.

22 R.F. Baumeister, M.R. Leary, The Need to Belong: Desire for Interpersonal Attachments as a Fundamental Human Motivation, „Psychological Bulletin” 117(1995), nr 3, s. 497-529. 
[śmiech]... no o prestiżu raczej nie było mowy. [...] Tata wyraźnie się oburzył i chyba jakby... zasmucił? Chyba go zawiodłem, spodziewał się po mnie więcej, bo dla niego zarabianie w taki sposób pieniędzy to ujma" (Z8, lat 24). Zdarzały się też wypowiedzi świadczące o nieco słabszych emocjach towarzyszących bliskim w związku z zawodową grą badanego, lecz nawet te przypadki nie są pozbawione swego rodzaju żalu i zawodu: „No wiadomo, że jak to rodzice chcieliby, żebym miał normalną pracę i tak dalej, ale wydaje mi się też, że zdają sobie sprawę, że... no że po prostu jest mi dobrze tak, jak jest teraz. No i myślę, że cały czas trzymają kciuki, że jednak będzie ze mną w porządku" (Z2, lat 27).

Powyższe wypowiedzi wskazują jednoznacznie na istniejącą w rodzinach badanych osób potrzebę akceptacji w szerszej społeczności i lęk przed wykluczeniem społecznym, które ma silnie negatywny wpływ na samopoczucie jednostki, zarówno na poziomie fizjologicznym, jak i psychologicznym ${ }^{23}$. Dla rodziców graczy ważna jest pozycja w kręgu swoich znajomych, a negatywne skojarzenia z grą w pokera narażają tę pozycję na zachwianie lub jej upadek.

Czterech z 12 graczy zawodowych wspomniało o niestabilnych zarobkach z gry, a co za tym idzie niedostatecznym bezpieczeństwie finansowym dla swojej rodziny: „Na grze można zarobić naprawdę dużo, porównując do znajomych, którzy pracują w różnych branżach, ale to nigdy nie będzie stała pensja. Jest jednak ta wariancja - są miesiące, że masz same wygrane, a są takie, gdzie wychodzisz na zero. Trochę brakuje tej stabilności. Chcąc mieć dzieci, to trzeba by się zastanowić, czy grając jestem w stanie zapewnić im bezpieczeństwo" (Z3, lat 30).

Opisane postawy rodzin wobec podejmowania gry przez respondentów prowadzą do realnych zmian w zachowaniu graczy, co zostało opisane w dalszej części artykułu.

\subsection{NEGATYWNE NASTAWIENIE BLISKICH DO POKERA A DALSZE PLANY DOTYCZĄCE GRY}

Reakcja rodziny na zaangażowanie się $\mathrm{w}$ grę w pokera nie pozostała bez echa w dalszym zachowaniu graczy. Często wywoływała wątpliwości odnośnie do gry. Jedną z reakcji na negatywne nastawienie rodziny była początkowa przekorność, głębsze angażowanie się w grę i szukanie zrozumienia wśród społeczności graczy. W przypadku graczy zawodowych wiązało się to z chęcią

23 J.B. Beekman, M.L. Stock, T. Marcus, Need to Belong, Not Rejection Sensitivity, Moderates Cortisol Response, Self-Reported Stress, and Negative Affect Following Social Exclusion, „The Journal of Social Psychology" 2016, nr 156, s. 131-138. 
udowodnienia, że możliwe jest kontynuowanie takiej ścieżki kariery i czerpanie z niej zysków. O takich odczuciach wspomniało 15 spośród 27 badanych osób (56\%): „Chciałem mimo wszystko spróbować, trochę im na złość, na przekór.” (Z5, lat 21); „W rodzinie nie znalazłem zrozumienia, to było przykre, bo przecież nie robiłem nic złego, dopóki miałem nad wszystkim kontrolę. [...] Z tego, co mówili inni gracze, u nich było podobnie" (Z11, lat 30).

Inni widząc, jakie emocje wywołuje u ich bliskich gra, od razu czuli do niej zniechęcenie: „Ja nawet sam nie wiedziałem, czy chcę grać i tak zarabiać na życie. Ale wiesz, jak masz takie 'wsparcie' i na start dostajesz kosę od najbliższych, to ci się odechciewa nawet próbować" (Z10, lat 29). Podobne odczucia miało 10 badanych osób (37\%).

W rodzinach i związkach respondentów z czasem pojawiało się ograniczenie zaufania w sferze finansów, o którym opowiedziało 11 graczy (41\%). Jeden z zawodowych pokerzystów powiedział: „Moja żona, wtedy w sumie narzeczona, zaczęła się czaić i podglądać moje wyniki... chodziło jej o pieniądze. Bo wiadomo, w pokerze nie masz stałych zarobków, że co miesiąc dostajesz na konto tyle i tyle, jak na etacie" (Z10, lat 29). Gracze rekreacyjni również spotykali się z podejrzliwością wobec kwot wydawanych na grę: „Czasem mam wrażenie, że mama specjalnie podpytuje o jakieś tam moje zakupy, żeby sprawdzić, czy mam za co kupić buty czy coś innego, bo myśli, że na pokera wydaję pół pensji” (R1, lat 21).

Opisane wyżej sytuacje, w których badanym najbardziej doskwierał brak zrozumienia ze strony bliskich, w perspektywie prowadziły do zmęczenia psychicznego i poczucia osamotnienia. Niektórzy gracze mówili o zbliżaniu się momentu zwrotnego, w którym będą musieli ustalić priorytety i podjąć decyzję o kontynuowaniu lub zakończeniu gry: „Czuję, że przyjdzie kiedyś taki dzień, kiedy powiem dość " (R5, lat 28).

\subsection{PRZYKŁADY ZAAKCEPTOWANIA GRY W POKERA PRZEZ RODZINE}

Choć większość badanych spotkała się z negatywną reakcją rodziców na wieść o rozpoczęciu przez nich gry w pokera, niektórzy z nich dość szybko zmienili swoje nastawienie (o takich sytuacjach opowiedziało 11 respondentów). Czasami już po krótkiej rozmowie stali się bardziej przychylni pomysłowi gry, byli otwarci na dyskusję o możliwych korzyściach z niej płynących i choć nadal wyrażali obawy oraz niepewność, zaufali synowi w kwestii kontroli nad grą i jej bezpieczeństwa: „Porozmawialiśmy o tym, wytłumaczyłem, jak do tego podchodzę. O dziwo mi uwierzyli, byłem chyba przekonujący i nie było z tym żadnego problemu. [...] Więc gdy porozmawialiśmy bardziej ściśle na ten temat, 
to [tata] powiedział: No okej, S., graj, ale uważaj na siebie. Masz moje wsparcie, wspieram cię, ale uważaj na siebie" (R4, lat 29).

Inni respondenci (9 osób) opowiadali o początkowym sprzeciwie rodziców wobec gry, który złagodniał z czasem. Silne emocje dotyczące obawy przed uzależnieniem, lęku przed opinią społeczną i wykluczeniem osłabły pod wpływem rozmów, a także na skutek obserwacji dojrzałego, rozsądnego sposobu gry, nad którą badani mieli widoczną kontrolę. Ostatecznie rodzice i inni bliscy zaakceptowali taki sposób rozrywki lub nawet zarabiania pieniędzy. Należy podkreślić, że wszystkie te osoby grały w sposób zdyscyplinowany i bezpieczny, traktując grę jako swoją pracę (w przypadku graczy zawodowych), co dało ich bliskim podstawy do zaufania i pozbycia się obaw.

Wszystkie takie przypadki to przykłady rodzin, w których relacje między dzieckiem a rodzicami opisane były jako bardzo dobre, ciepłe, pełne zaangażowania z obu stron. Na silne więzi wskazywały także wypowiedzi niektórych respondentów świadczące o tym, że kierują się w życiu zasadami, które przekazali im rodzice, a wartości wyniesione $\mathrm{z}$ domu rodzinnego są dla nich ważne. $\mathrm{Na}$ ten temat wypowiedziało się 9 osób, wypowiedź jednej z nich brzmiała: „Zasadniczo żyję wartościami, które były też ważne dla moich rodziców. Planujemy z narzeczoną ślub, później planujemy dzieci, jest edukacja ważna. Z takich ogólników to święta spędzamy razem, lubimy razem spędzać czas. [...] Tak że wszystko to, czego nauczyli mnie w domu, jest dla mnie ważne" (R10, lat 25).

\section{ZAKOŃCZENIE}

Akceptacja bliskich osób odnośnie do wykonywanego zawodu czy nawet sposobu spędzania wolnego czasu, tak jak w wielu innych sferach życia, jest bardzo ważna i potrzebna do swobodnego podejmowania dalszych decyzji. Dzieje się tak dlatego, że każda grupa społeczna jest dla człowieka ważna, jednak w rodzinie więzy i wzajemne oddziaływanie na siebie jej członków mają wyjątkową siłę. Co więcej, istnieją potrzeby, które jest w stanie zaspokoić jedynie rodzina. Żadna inna grupa nie może zastąpić jej w tworzeniu związków niezbędnych do prawidłowego funkcjonowania psychicznego, zaspokajających potrzebę miłości, akceptacji i szacunku ${ }^{24}$. To powoduje dbałość o rodzinne więzy, a co za tym idzie, branie pod uwagę postawy bliskich wobec podejmowanych aktywności.

Gracze pokerowi, choć zdają sobie sprawę z nietypowości wybranej przez siebie formy spędzania czasu lub zarabiania pieniędzy, mają nadzieję na jej akceptację

${ }^{24}$ M. Braun-GatkowsKa, Psychologia domowa, Kraków: Wydawnictwo Naukowe Akademii Ignatianum w Krakowie 2018, s. 20-26. 
ze strony bliskich. Oni z kolei, jak wszyscy ludzie, są uwikłani w rozmaite więzy społeczne i przynależą do różnych grup, w których członkostwo jest dla nich cenne. Ponieważ gra w pokera, szczególnie zawodowa, nie jest akceptowana przez społeczeństwo, rodzi to sytuacje konfliktowe. Ponadto ważnym aspektem jest możliwość uzależnienia się od pokera. Gracze stają zatem przed niełatwym dylematem. Niektórzy z nich zniechęcają się do pokera i planują zakończyć grę, inni mimo wszystko ją kontynuują. Są jednak rodziny, które osiągają porozumienie w tej kwestii, akceptując wybór pokerzysty, pod warunkiem, że jego podejście do gry jest dojrzałe i bezpieczne. Czynnikiem, który zaważa na ostatecznej akceptacji gry, jest relacja ukształtowana między członkami rodziny przed momentem rozpoczęcia gry. Osoby, które oceniają stosunki z rodzicami jako bardzo dobre i ciepłe, mają szansę na akceptację i wsparcie bliskich we własnych decyzjach, nawet tak kontrowersyjnych.

\section{BIBLIOGRAFIA}

American Psychiatric Association, Diagnostic and Statistical Manual of Mental Disorders Fifth Edition, Washington 2013.

Badora B., Gwiazda M., Herrmann M., Kalka J., Moskalewicz J., Oszacowanie rozpowszechnienia oraz identyfikacja czynników ryzyka i czynników chroniących w odniesieniu do hazardu, w tym hazardu problemowego (patologicznego) oraz innych uzależnień behawioralnych, Warszawa: Centrum Badania Opinii Społecznej 2012.

Badora B., Gwiazda M., Herrmann M., Kalka. J. Moskalewicz J., Rozpowszechnienie wybranych uzależnień behawioralnych i ich związek z używaniem substancji psychoaktywnych, Warszawa: Centrum Badania Opinii Społecznej 2015.

Baumeister R.F., Leary M.R., The Need to Belong: Desire for Interpersonal Attachments as a Fundamental Human Motivation, „Psychological Bulletin” 117(1995), nr 3, s. 497-529.

Beekman J.B., Stock M.L., Marcus T., Need to Belong, Not Rejection Sensitivity, Moderates Cortisol Response, Self-Reported Stress, and Negative Affect Following Social Exclusion, „The Journal of Social Psychology" 156(2016), issue 2, s. 131-138, doi: 10.1080/00224545.2015.1071767.

Biolcati R., Passini S., Griffiths M.D, All-in and Bad Beat: Professional Poker Players and Pathological Gambling, „International Journal of Mental Health and Addiction” 13(2014), issue 1, s. 19-32, doi:10.1007/s11469-014-9506-1.

Braun-GaŁkowska M., Psychologia domowa, Kraków: Wydawnictwo Naukowe Akademii Ignatianum w Krakowie 2018.

Czajkowk M., Poker - gra szczęścia czy umiejętności? Przegląd analiz teoretycznych i empirycznych oraz wnioski dla regulacji, „Ekonomia” 2015, nr 40, s. 33-57.

Denzin N.K., Lincoln Y.S., Introduction: the discipline and practice of qualitative research, w: Handbook of qualitative research, red. N.K. Denzin, Y.S. Lincoln, Thousand Oaks CA: Sage Publications 2005, s. 1-45.

Dufour M., Brunell N., Roy E., Are Poker Players All the Same? Latent Class Analysis, „Journal of Gambling Studies" 2015, nr 31, s. 441-454, doi: 10.1007/s10899-013-9429-y.

DzIERZYŃSKa-Breś S., Sytuacja społeczna rodzin osób pozbawionych wolności, Poznań: Wydawnictwo Naukowe UAM 2016. 
Ferris J., Wynne H., The Canadian Problem Gambling Index: Final Report, Ottawa: Canadian Centre on Substance Abuse 2001.

Gaebel W., Zielasek J., Reed G.M., Zaburzenia psychiczne i behawioralne w ICD-11: koncepcje, metodologie oraz obecny status, „Psychiatria Polska” 2017, nr 51(2), s. 169-195, doi: https:// doi.org/10.12740/PP/69660.

Hamer H., Psychologia społeczna: teoria i praktyka, Warszawa: Difin 2005.

Hopley A.A.B., Wagner J., Nicki R., Making a Living Online: Problem Gambling and Workaholism in High Earning Online Texas Hold'em Poker Players, „Journal of Gambling Issues” 2014, nr 29, s. 1-18, doi:10.4309/jgi.2014.29.5.

Kahneman D., Pułapki myślenia: o myśleniu szybkim i wolnym, Poznań: Media Rodzina 2012.

Kubiak-Krzywicka W., Interakcyjno-kontekstualny model zaburzonej socjalizacji, Poznań: Wydawnictwo Naukowe UAM 2010.

LELONEK-KuLETA B., Uzależnienie od grania hazardowego w rodzinie na tle wybranych kultur, w: Rodzina i tradycja - na pograniczu kultur i czasów, red. J. Gorbaniuk, Lublin-Kijów-Lwów 2015, s. 124-144.

MAKARUK K., WóJCIK S., EU NET ADB - Badanie nadużywania internetu przez młodzież w Polsce i Europie. Raport z badań, Warszawa: Fundacja Dzieci Niczyje 2012.

Mielecka-Kubień Z., Biolik J., Warzecha K., Wójcik A., Wybrane aspekty społeczno-ekonomicznych skutków uzależnienia od hazardu, „Zeszyty Naukowe Uniwersytetu Ekonomicznego w Krakowie" 2015, nr 4(940), s. 85-99.

Muda R., ŚlıwińsKa P., PAwelec A., I-graj z losem dzięki umiejętnościom. Jakie czynniki związane są z wysokimi osiągnięciami finansowymi w grze w pokera?, „Psychologia Ekonomiczna” 2014, nr 5, s. 26-28, wydanie internetowe: https://psychologia-ekonomiczna.com.pl/article/view/226.

Sproston K., Hing N., Palankay Ch., Prevalence of Gambling and Problem Gambling in New South Wales, Sydney: NSW Office of Liquor, Gaming and Racing 2012.

Wardle H., Moody A., Spencer S., Orford J., Volberg R., Jotangia D., Griffiths M., Hussey D., DobBie F., British Gambling Prevalence Survey 2010, National Center for Social Research 2010.

\section{POSTAWY RODZINY WOBEC GRY W POKERA - WYNIKI BADAŃ JAKOŚCIOWYCH GRACZY REKREACYJNYCH I ZAWODOWYCH}

\section{Streszczenie}

Gra w pokera jest dość popularną rozrywką, bywa również nietypową formą pracy. Może jednak prowadzić do uzależnienia, mającego negatywne skutki dla jednostki i społeczeństwa, ponadto nie jest akceptowana w społeczeństwie. Dlatego rodziny graczy mogą mieć obawy dotyczące skutków podejmowania gry. Potwierdzają to wyniki badań jakościowych opisane w niniejszym artykule. Przeprowadzono 30 wywiadów pogłębionych z udziałem rekreacyjnych i zawodowych graczy pokerowych w wieku 19-30 lat, których celem było m.in. poznanie sytuacji rodzinnej pokerzystów. Artykuł prezentuje wyniki dotyczące postaw rodzin wobec gry, które w większości były pełne lęku i wątpliwości. Opisane zostały uwarunkowania ich negatywnego nastawienia, u podstaw którego leżą często mechanizmy życia społecznego oraz lęk przed uzależnieniem od gry, a także ich konsekwencje dotyczące dalszych planów graczy. Mowa jest również o relacjach rodzinnych pełniących ważną rolę w kwestii akceptacji gry w pokera.

Słowa kluczowe: poker; hazard; rodzina; uzależnienie; akceptacja społeczna. 